\title{
PERANAN PENGETAHUAN GIZI IBU HAMIL DAN IBU MENYUSUI TERHADAP KECERDASAN ANAK MELALUI PENDIDIKAN KESEJAHTERAAN KELUARGA
}

\author{
Oleh \\ Damiati \\ Jurusan Pendidikan Kesejahteraan Keluarga, FTK, UNDIKSHA
}

\begin{abstract}
ABSTRAK
Pendidikan Kesejahteraan Keluarga salah satu pendidikan formal dengan program regular yang diselenggarakan di sekolah dimana mempunyai tujuan untuk menjadikan anak didik menjadi kreatif sehingga dapat menggeneralisasikan, mengabstrakkan, dan menemukan hubungan sehingga dapat mengemukakan pendapat dan bersikap, selain itu dapat menumbuhkan nilai-nilai insani dan ilahi dalam masyarakat. Untuk itu anak perlu mendapatkan pendidikan melalui asuhan dan bimbingan serta pengawasan dari orang tua selain di sekolah.

Agar anak dapat tumbuh kembang dengan optimal orang tua harus memenuhi kebutuhan faali anak yaitu kebutuhan anak dalam mendapatkan makanan bergizi mulai dalam kandungan sampai dilahirkan yang berguna untuk pertumbuhan badan perkembangan kecerdasannya.

Keadaan perkembangan otak sangat terpengaruh apabila kurang gizi terjadi sejak dalam kandungan dan berlanjut sampai usia bayi.

Keadaan malnutrisi akan mengganggu pertumbuhan dan perkembangan janin yang dikandungnya dan memberi dampak terjadinya inferior. Untuk itu diperlukan gizi yang cukup bagi calon ibu dan ibu hamil agar anak yang dilahirkan sehat dan kelak merupakan sumber daya yang berkualitas dan dapat diandalkan untuk bersaing di era globalisasi.
\end{abstract}

Kata-kata kunci : Gizi ibu hamil dan menyusui, kecerdasan anak, Pendidikan PKK

\begin{abstract}
Home economics education is one the formal educational programs taught at school with the objective of promoting creaticity in children that enables them to generalize, abstract, and discover relation in such a way that they can express options and show a good attitude beside being capable of humen and divini values in the community. As the conseqcuence, the children need to get an education at school.

To make the children grow and develop at the optimum level, the parents have to the physiological nutrion requirements, i.e., the children's need for nutrition starting from the prenatal period to the birth to make them able to grow and develop physically and intellectually.
\end{abstract}


The low rate of the brain growth depends very much the nutrition and if malnutrition occurs since the prenatal period and continues after the childhood.

Malnutrition will hinder fetal gwoth and development and is responsible for inferiority. Hence, prospective mothers and pregnant women need sefficient nutrition to deliver healthy babies who will become quality humen secources in the future who can compete in the globalization era.

Keywords : Pregnant women and breasfeeding mothers, child intelegence, home economics education

\section{PENDAHULUAN}

Peningkatan akses masyarakat terhadap pendidikan yang lebih berkualitas merupakan mandat yang harus dilakukan bangsa Indonesia sesuai dengan tujuan negara Indonesia yang tertuang dalam pembukaan UUD 1945.

Pendidikan merupakan salah satu pilar penting dalam meningkatkan kualitas manusia, bahkan kinerja pendidikan yaitu gabungan angka partisipasi kasar (APK) jenjang pendidikan dasar sampai dengan pendidikan tinggi dan angka melek aksara digunakan sebagai variabel dalam menghitung indeks pembangunan manusia (IPM), bersama-sama dengan variabel kesehatan dan ekonomi. Oleh karena itu pembangunan pendidikan Nasional harus mampu menjamin pemerataan kesempatan pendidikan, dan meningkatkan mutu pendidikan untuk menghadapi tantangan sesuai dengan tuntutan perubahan kehidupan lokal, nasional dan global.

Pendidikan kesejahteraan keluarga secara formal disampaikan di sekolah dan pendidikan ini mengarah pada pendidikan intelektual sebagai pembentukan pribadi dan sumber daya manusia yang optimal. Dalam pendidikan kesejahteraan keluarga lebih ditekankan pada penguasaan diri dalam hal menjunjung nilai-nilai yang mulai ditanamkan pada anak-anak, begitu pula mempelajari peran-peran sosial melalui interaksi sosial dalam keluarga dengan mempelajari peran sebagai anak, sebagai saudara ( kakak/adik), dan sebagainya. Oleh karena itu agar anak tumbuh kembang dengan optimal peran serta keluarga, sekolah dan masyarakat perlu ditingkatkan melalui asuhan, bimbingan, pembelajaran, dan pelatihan sesuai dengan kehidupan keluarga. 
Pembangunan kependudukan dan keluarga yang berkualitas, memiliki peran yang sangat penting dalam bidang kesehatan guna meningkatkan kualitas sumber daya manusia. Kualitas manusia Indonesia sangat ditentukan oleh anak Indonesia yang tumbuh dan berkembang menjadi dewasa di lingkungannya. Dalam usaha menciptakan sumber daya manusia yang berkualitas perlu upaya dari berbagai pihak terutama keluarga sebagai tempat pertama dan utama tumbuh kembang anak dengan melakukan perawatan yang baik semenjak janin melalui kesehatan ibu, terutama bagi ibu hamil dan ibu menyusui untuk itu diperlukan asupan gizi yang baik untuk pertumbuhan dan perkembangan bayi. Dalam memenuhi kebutuhan ibu hamil dan ibu menyusui diharapkan seorang ibu dapat memenuhi kebutuhan gizinya degan memenuhi cukup kalori, protein, mineral dan vitamin guna memenuhi kenutuhan zat gizi ibu, janin, plasenta dan bayi bila kelak dilahirkan. Dalam hal ini gizi merupakan salah satu faktor yang berpengaruh pada proses tumbuh kembang fisik, syaraf, otak tingkat intelektualitas, dan kecerdasan manusia.

Tingkat kecerdasan atau intelegensi adalah kemampuan dasar yang mempengaruhi seseorang dalam menangani tugas yang sifatnya kognitif yang dipengaruhi oleh faktor internal dan eksternal. Faktor internal adalah faktor dari dalam dalam hal ini yang berperan adalah kromosom yang berasal dari ayah dan ibu, sedangkan faktor eksternal adalah lingkungan dalam rahim ibu, keadaan gizi ibu sebelum dan selama hamil.

Dari latar belakang diatas, makalah ini akan membahas tentang peranan pendidikan kesejahteraan keluarga dalam meningkatkan pengetahuan gizi ibu hamil terhadap kecerdasan anak guna menciptakan sumber daya manusia yang berkualitas.

\section{PEMBAHASAN}

Pendidikan Kesejahteraan Keluarga salah satu pendidikan formal dengan program reguler yang diselenggarakan di sekolah, dimana mempunyai tujuan untuk menjadikan anak didik menjadi kreatif sehingga dapat menggeneralisasikan, mengabstrakkan dan menemukan hubungan pengetahuan sehingga dapat mengemukakan pendapat dan dapat bersikap. Selain itu dapat menumbuh kembangkan nilai-nilai insani dan ilahi dalam masyarakat. 
Kualitas anak sangat ditentukan oleh kualitas tumbuh kembangnya yang didapatkan dari pendidikan anak dalam keluarga, sekolah dan masyarakat. Pendidikan kesejahteraan keluarga mempunyai kemampuan dan kekuatan individu untuk memiliki keterampilan dan pengetahuan untuk mencapai sumber daya manusia yang berkualitas dimana peran keluarga sangat menentukan dalam tumbuh kembang dengan perawatan mulai dari janin sampai dilahirkan melalui peningkatan kesehatan ibu.

Hampir semua orang memerlukan makan setiap kali di rumah masingmasing, dengan demikian maka gizi dalam keluarga perlu adanya dan perlu pula ada perbaikannya melalui pendidikan keluarga karena didalam keluarga biasanya ibu-ibu berperan dalam mengatur makanan keluarga, oleh karena itu ibu-ibu adalah sasaran utama dalam pendidikan gizi keluarga.

Pendidikan gizi keluarga bertujuan mengubah perbuatan-perbuatan orang yang salah, yang mengakibatkan bahaya gizi kurang seperti kurang gizi pada ibu hamil dan menyusui, defisiensi gizi pada bayi dan balita sehingga pertumbuhan dan perkembangannya tidak optimal.

Usaha perbaikan gizi pada anak dan wanita hamil akan mengurangi tingkat kematian anak dan mengurangi keguguran kandungan. Hal ini akan mengurangi kebutuhan kelahiran yang sering, memungkinkan penjarangan kelahiran, dan pada waktunya mengurangi tingkat kelahiran.Oleh karena itu usaha-usaha perbaikan gizi dikaitkan dengan program posyandu. Melalui integrasi kedua kegiatan ini maka wanita dalam usia melahirkan dan anak-anak akan mendapat pelayanan paket gizi dan penyuluhan gizi di tempat dan waktu yang sama melalui program posyandu.

Agar anak dapat tumbuh sehat secara fisik (badan) dan psikis (jiwa), orang tua dan lingkungan sekolah harus dapat memenuhi kebutuhan dasarnya mulai dari kebutuhan faali, kebutuhan akan keamanan dan rasa aman, kebutuhan akan kasih sayang dan kebersamaan, kebutuhan akan penghargaan sampai dengan kebutuhan akan perwujudan diri, dimana kebutuhan tersebut saling bergantung dan medukung satu dengan lainnya. Kebutuhan faali merupakan kebutuhan anak dalam mendapatkan makanan bergizi sampai dilahirkan yang berguna untuk pertumbuhan badan yang sehat, dan untuk perkembangan kecerdasannya. 
Kecerdasan atau intelegensi memang bukan satu-satunya faktor yang menentukan keberhasilan seseorang, akan tetapi merupakan modal dasar yang penting untuk mencapai keberhasilan, untuk itu diperlukan pengetahuan gizi dan kesehatan dalam memenuhi kebutuhan faali, terutama pada ibu hamil.

Masalah kesehatan ibu dan anak merupakan masalah Nasional yang perlu dan mendapat prioritas utama, karena sangat menentukan kualitas dumber daya manusia pada generasi mendatang. Dewasa ini derajat kesehatan ibu dan anak di Indonesia masih belum memuaskan hal ini namapak masih tingginya angka kematian ibu dan anak. Tingginya angka kematian ibu dan anak, serta lambatnya penurunan kedua angka tersebut, menunjukkan bahwa pelayanan kesehatan ibu dan anak perlu dilakukan upaya peningkatan pelayanan kesehatan.

Rawannya derajat kesehatan ibu ini memberikan dampak yang bukan terbatas pada kesehatan ibu saja, tapi juga berpengaruh secara langsung terhadap derajat kesehatan janin/bayi. Gizi merupakan hal yang sessensial bagi ibu hamil, pertumbuhan dan perkembangan janin tidak dapat optimal apabila asupan makanan dan zat gizi lainnya secara adekuat pula. Untuk dapat berlangsungnya kehamilan yang optimal diperlukan kondisi yang prima dan gizi yang lebih baik dibandingkan dengan wanita yang tidak hamil, karena dibutuhkan untuk menjaga kesehatan ibu, memenuhi kebutuhan gizi janin serta persiapan prosuksi air susu ibu (ASI). Penataan gizi pada ibu hamil dan menyusui adalah untuk menyiapkan (1) cukup kalori, protein yang bernilai biologi tinggi, vitamin, mineral dan cairan untuk memenuhi kebutuhan zat gizi ibu, janin/bayi.(2) makanan padat kalori dapat membentuklebih banyak jaringan tubuh bukan lemak, (3) cukup kalori dan zat gizi untuk memenuhi pertambahan berat baku selama hamil ataupun berat badan bayi terutama bagi ibu yang menyusui, (4) perencanaan perawatan gizi yang memungkinkan ibu hamil dan ibu menyusui untuk memperoleh dan mempertahankan statusgizi optimal sehingga dapat menjalani kehamilan dengan aman, dan kelak melahirkan bayi dengan fisik dan mental yang baik dan dapat mempersiapkan asi sengan sempurna, (5) perawatan gizi yang dapat mengurangi atau menghilangkan reaksi yang tidak diinginkan, seperti mual dan muntah, (6) perawatan gizi yang adapat membantu pengobatan penyulit yang yrjadi selama kehamilan dan dapat memperlancar asi, (7) mendorong 
ibu hamil sepanjang waktu untuk mengembangkan kebiasaan makan yang baik yang dapat meningkatkan dan memperlancar produk asi.

\subsection{Peranan Gizi Terhadap Perkembangan Otak}

Gizi merupakan faktor yang sangat penting bagi ibu yang sedang hamil dan janin yang dikandungnya. Janin pada prinsipnya merupakan parasit dimana kebutuhan untuk pertumbuhan dan perkembangannya diperoleh dari ibu melalui plasenta. Untuk memenuhi kebutuhan gizi bagi keduanya diperlukan pasokan yang lebih tinggi kualitas maupun kuantitas dibandingkan dengan ibu yang tidak hamil. Kecukupan gizi pada wanita sebelum dan selama hamil mutlak diperlukan agar dapat menghasilkan manusia yang berkualitas.

Zat-zat gizi yang diperlukan sangant bervariasi, kekurangan satu atau beberapa zat gizi pada masa hamil dan setelah kelahiran akan mengakibatkan gangguan pada tingkat kecerdasan dan perkembangan intelektual anak.

Sel neuron dan glia mulai dibentuk pada trisemester pertama kehamilan, pertumbuhan ini berlangsung dengan cepat selama periode kehamilan dan diteruskan beberapa waktu sesudah bayi dilahirkan sampai bayi berumur 2-3 tahun dengan periode kehamilan tercepat 6 bulan pertama. Sesudah itu praktis tidak ada pertumbuhan lagi, kecuali pembentukan sel-sel neuron baru untuk mengganti sel-sel yang rusak atau mati.

Keadaan gizi ibu akan mempengaruhi pertumbuhan dan perkembangan fungsi organ pada janin. Semasa dalam kandungan perkembangan otak janin sudah dipengaruhi oleh gizi bila tidak terpenuhi secara optimal maka akan terjadi gangguan intelektual. Ibu dengan kekeurangan gizi, kemungkinan besar akan melahirkan bayi dengan berat badan lahir rendah dan mengalami gangguan pada otak.

Protein dan energi sangat diperlukan dalam proses pembentukan neurotrasmiter jika kebutuhan protein dan energi tidak terpenuhi, maka perbanyakan jumlah sel otak janin akan terganggu atau terhenti, dan ukuran kepala serta otak janin menjadi lebih kecil secara proporsional terhadap ukuran tubuh. Walaupun ukuran otak bukan satu-satunya indikator intelegensi, banyak bukti 
menunjukkan bahwa otak berukuran kecil terkait dengan intelegensi rendah dan fungsi otak kurang ( Karyadi, D., 199)

Terpenuhi kebutuhan protein dan energi dapat dilihat dari kenaikan berat badan sebanyak 10-12 kg selama kehamilan. Kebutuhan vitamin dan mineral saat kehamilan juga perlu mendapat perhatian. Zat besi $(\mathrm{Fe})$ diperlukan untuk energi, pengangkutan oksigen serta penyusunan neurotransfer dan DNA. Asam folat diperlukan dalam sintesa protein, lemak, DNA, RNA. Vitamin C berperan dalam pembentukan sel baru dan proses meilinisasi. Seng ( $\mathrm{Zn}$ ) diperlukan untuk methabolisme energi dan sintesis DNA, RNA, dan protein. Asam lemak W-3 berperan penting dalam perkembangan otak dan jaringan syaraf pada janin.

\subsection{Dampak Gizi Buruk Terhadap Perkembangan Otak Janin}

Pada waktu hamil perkembangan otak janin dipengaruhi oleh gizi, keadaan malnutrisi akan menjadi besar pengaruhnya apabila terjadi dalam kandungan, karena periode ini semua organ tubuh mengalami pertumbuhan yang pesat. Jika ibu hamil kekurangan zat gizi akan menyebabkan berkurangnya zat-zat gizi yang ditransfer kepada janin. Selain itu pembentukan plasenta akan menjadi abnormal sehingga secara langsung atau tidak langsung dapat menyebabkan kesulitan dalam mentransfer zat-zat gizi kepada janin. Dengan sendirinya akan menghambat pembelahan sel dalam otak.

Kekurangan gizi saat hamil dapat juga menyebabkan kelahiran dengan berat badan lahir rendah. Bayi yang lahir dengan berat badan rendah dalam perjalanan hidupnya akan lebih parah lagi, bila tidak diikuti dengan pemberian makanan yang bernilai gizi tinggi serta lingkungan yang miskin. Kekurangan gizi pada masa dini perkembangan otak akan menghentikan sintesis DNA yang mengakibatkan berkurangnya pertumbuhan otak, sehingga sedikit sel-sel otak yang berukuran normal dan dapat dipastikan akan berpengaruh pada intelektual anak (Soetjiningsih, 1995).

Defisiensi vitamin dan zat-zat gizi tertentu pada awal trimester I yaitu pada periode pembentukan otak, dapat menyebabkan kegagalan pembentukan organ otak yang sempurna sehingga dapat mengakibatkan cacat bawaan pada susunan syaraf 
otak janin. Pada trimester II defisiensi gizi dapat mengganggu pembentukan neuroblast yang berakibat pengecilan ukuran kepala janin sehingga terjadi microcephaly yang berkaitan dengan penurunan kecerdasan. Kekeurangan yodium pada gizi ibu hamil dapat menyebabkan kritinisme (kerdil), mental retardation dengan penurunan kecerdasan.

\subsection{Peran ASI Dalam tumbuh kembang bayi}

Makanan yang baik bagi badi diseluruh dunia adalah ASI, karena pada asi terdapat susunan zat dan mutu untuk pertumbuhan yang paling baik dan sempurna, karena ASI mengandung sebagian bessar air, protein 1,3\%, lemak 4,5\%, zat gula susu dan aneka ragam garam-garam mineral berupa zat kapur, zat besi,dan zat pelindung sebesar $7 \%$, dan semua zat gizi tersebut mudah dicerna oleh bayi.

Selain peranannya yang sangat penting sebagai bahan pangan dan minuman untuk bayi, ASI mempunyai banyak keuntungan lain yaitu :

1. Tidak memerlukan persiapan khusus

2. Terlindung dari kotoran dan penularan kuman-kuman penyakit (asalkan si ibu sehat dan selalu menjaga hygiena pribadi)

3. Mudah diisap oleh bayi

4. Suhu sudah sesuai dengan kebutuhan bayi

5. Mengandung beragam zat anti body yang dapat menolak penyakityang tidak terdapat pada susu formula

6. Terjalin hubungan batin dan kasih sayang langsung antara bayi dan ibu

7. Ekonomis, karena tidak perlu menyisihkan dana khusus untuk membeli susu formula.

\section{PENUTUP}

Dalam usaha menciptakan sumber daya manusia yang berkualitas perlu upaya dari berbagai pihak terutama keluarga sebagai tempat pertama dan utama tumbuh kembang anak. Dengan memberikan perawatan yang baik dimulai semenjak janin sampai anak dilahirkan melalui peningkatan pengetahuan ibu tentang kesehatan dan gizi, karena gizi merupakan salah satu faktor yang berpengaruh pada 
proses tumbuh kembang fisik, sistem syaraf, otak, tinggkat intelektualitas dan kecerdasan anak.

Kecerdasan anak atau intelegensi memang bukan satu-satunya faktor yang menentukan keberhasilan seseorang, akan tetapi merupakan modal dasar yang penting untuk mencapai keberhasilan. Untuk itu diperlukan pengetahuan kesehatan dan gizi dalam memenuhi kebutuhan anak terutama kebutuhan faali.

Keadaan perkembangan otak sangat terpengaruh apabila terjadi kekurangan gizi pada masa kehamilan karena pada janin dalam kandungan, pertumbuhan otak terutama poliferatif dimana pembelahan sel terjadi sangat pesat. Kekurangan gizi pada pada ibu dapat menyebabkan gangguan pertumbuhan sehinga mengakibatkan terganggunya pembelahan sel dalam otak.

Keadaan malnutrisi akan mengganggu pertumbuhan dan perkembangan janin yang dikandung oleh seorang ibu dan memberi dampak terjadinya inferior. Untuk itu diperlukan gizi yang cukup bagi calon ibu dan ibu hamil agar anak yang dilahirkan sehat dan kelak merupakan sumber daya manusia yang berkualitas dan dapat diandalkan untuk bersaing di era globalisasi.

\section{DAFTAR PUSTAKA}

Arisman, MB, 2004, Gizi Dalam Dauh Kehidupan, Buku Kedokteran (EGC) : Jakarta

Beni Karyadi, 1998, Peranan Gizi Dalam Meningkatkan Kecerdasan Anak, Depkes RI

Budiarso, Wiryawan, 1999, Pelayanan Kesehatan Ibu Hamil Dan Persalinan DSKI 1997, Badan Penelitian dan Pengembangan Kesehatan, Depkes RI.

Connny Semiawan, dkk, 1995, Pengenalan dan Pengembangan Bakat Sejak Dini, Remaja Rosdakarya : Bandung

Darwin, K, 1990, Peranan Gizi terhadap Kecerdasan Otak Anak, Persagi Jakarta.

Nung Muhajir, 2000, Ilmu Pendidikan Dan Perubahan Sosial (Teori Pendidikan Pelaku sosial Kreatif, Rake sarasin : Yogyakarta

Padji, 1995, Peningkatan Keterampilan Otak Anak Menyongsong Masa depan Yang Lebih Cemerlang, Pionir Jaya : Bandung 
Roy Tjiong, 1991, Problem Etis Upaya Kesehatan, Gramedia Pustaka Utama : Jakarta

Soetjiningsih, 1995, Tumbuh Kembang Anak, Buku Kesehatan EGC : Jakarta

Vembriarto, 1990, Sosiolgi Pendidikan, Paramiata : Yogyakarta

Zulkifli, 1999, Psikologi Perkembangan, Remaja Rosdakarya : Bandung

JPTK, UNDIKSHA, Vol. 10, No. 2, Juli 2013 : 73 - 82 